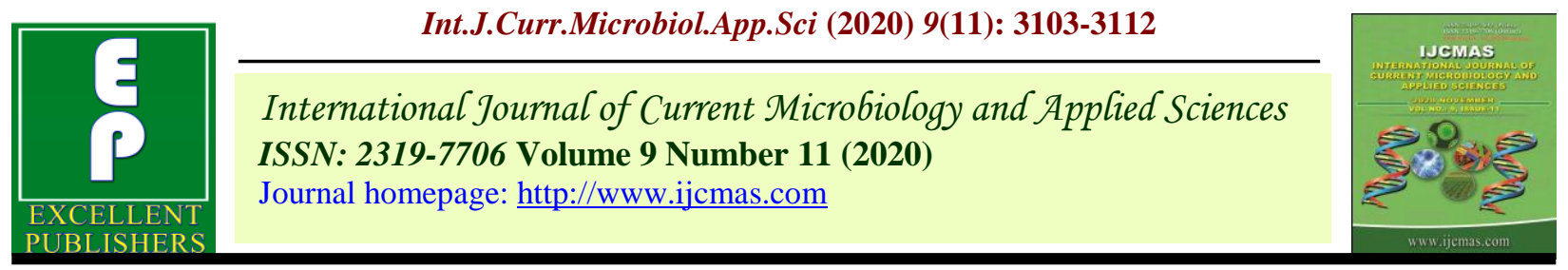

Original Research Article

https://doi.org/10.20546/ijcmas.2020.911.374

\title{
Development of Self-Propelled Onion Digger for Small Farmers
}

\author{
P. Dhananchezhiyan ${ }^{1} *$, P.K. Nanthinee ${ }^{2}$, E. Naveen Kumar ${ }^{2}$ and P. Parthiban ${ }^{2}$ \\ ${ }^{1}$ Department of Farm Machinery and Power Engineering, Agricultural Engineering College \\ and Research Institute, Tamil Nadu Agricultural University, \\ Coimbatore-641003, Tamil Nadu, India \\ ${ }^{2}$ Agricultural Engineering College and Research Institute, Kumulur, Trichy-621712, India \\ *Corresponding author
}

\begin{tabular}{|l|}
\hline Key w o r d s \\
Onion, Digger, \\
$\begin{array}{l}\text { Digging efficiency } \\
\text { and bulb damage }\end{array}$ \\
\hline Article Info \\
\hline $\begin{array}{l}\text { Accepted: } \\
22 \text { October } 2020 \\
\text { Available Online: } \\
10 \text { November } 2020\end{array}$ \\
\hline
\end{tabular}

\section{A B S T R A C T}

Onion harvesting machinery like all other farm equipment has passed through various stages of development. Our research work had focused on ease of handling and harvesting of onion in less time for small land holders at low cost by considering different factors as power requirement, cost of equipment, ease of operation and time of operation. Self-propelled onion digger required only one person to operate. Our Design objective is to come up with a self-propelled onion digger that was easily transportable, durable, easy to operate and maintainable for small farmer. By conventional method of harvesting one ha of land requires 96 man-hours, which accounts for Rs.4800/ha. Thus, keeping this in view to reduce labor cost, we developed the machine of cost Rs.15,584 which can harvest one ha of land in 8 hours. The maximum digging efficiency of the self-propelled onion digger is $97 \%$ and minimum plant damage percentage is $1.67 \%$.The savings in cost and time by using self-propelled onion digger compared with traditional method of harvesting is $81.9 \%$ and $91.3 \%$.

\section{Introduction}

India is the world's second largest producer of onion (Allium cepa L.) after China and it is one of the most important bulbs as well as cash vegetable crop belongs to family Alliaceous. In India, onion is being grown in an area of 5.30 million hectare which gives total production of 88.48 million tons with productivity 16.70 tons per hectare. In India, Onion crop is grown in about 1.20-millionhectare area with an annual production of 19.40 million tons with productivity 16.12 tons per hectare (Anonymous 2017). Mechanization of onion harvesting is needed as traditionally; the well-matured bulbs are harvested by hand shovel (khurpa) which requires $21.4 \%$ of total expenditure of onion 
cultivation. Also, it is necessary to complete the harvesting operation of onion within specified time limits for reduced harvest losses and higher storage life. For onion growers in India an economical partial mechanized onion harvesting would be a mechanical harvester which can dig the onion, help detaching soil and mixture, separating soil mass and finally windrowing the harvested crop which can be picked up manually. Onion was planted in flatbed or broad-based furrow (BBF) with a spacing of $15 \times 10 \mathrm{~cm}$ for both. Onion were generally harvesting by hand due to the high damages caused by the mechanical harvesting. Even though due to the lack of laborers in agricultural work, mechanical harvester for onion is need of the hour. Manual harvesting of onions is a tedious, time consuming, labor intensive and costly operation so mechanization of harvesting is essentially needed. Mechanization of onion harvesting needs as traditionally, the well-matured bulbs are harvested by hand shovel (khurpa) which requires 21.4 per cent of total expenditure of onion cultivation (Ashwini et al., 2014). Lorenzo and Abenavoli et al., (2004) reported that manual harvesting alone, accounts for more than $50 \%$ of total production costs. Mechanized harvesting (by means of onion pullers, windrowers, harvesters and, possibly, stem cutters), instead, results in work productivity 5 to 6 times higher than that of manual operations. The aim of the study is to develop and evaluate a prototype onion digger for small farmers.

Jafar Massah et al., (2012) found at vehicle speed of $1.8 \mathrm{~km} / \mathrm{h}$ and the blade angle of 20 degree. The percentage of the damaged bulbs caused by the harvester was less than the manual method. Mahesh C.S (2014) developed and evaluated digger performance at the experimental site. The digger was operated with a speed of $4 \mathrm{~km} / \mathrm{h}$ in first high gear with minimum losses at a field capacity of $0.46 \mathrm{ha} / \mathrm{h}$. Depth control wheels were effective to control the depth of cut by blade. The average operational depth of $7.62 \mathrm{~cm}$ of the developed digger was suitable with practically no damage to the onion bulbs. Lift percentage, mean digger efficiency and damage percentage were $94.9,89.8$ and $5.1 \%$, respectively. Budhale et al., (2019) reported that the depth of onion harvesting was depending upon depth of onion in soil bed. As per considering average biometric properties of onion the depth of harvesting is in range of $7-10 \mathrm{~cm}$. So, for harvesting without damage to onion crop the depth of operation was selected as $10 \mathrm{~cm}$. Omar et al., (2018) indicated that, the maximum field capacity was $0.180 \mathrm{fed} / \mathrm{h}$ at speed of $1.125 \mathrm{~km} / \mathrm{h}$ and the maximum field efficiency was $73.9 \%$ at speed of $0.720 \mathrm{~km} / \mathrm{h}$, it was recorded at depth of $4 \mathrm{~cm}$, compared with manual method which recorded the field capacity and field efficiency were $0.125 \mathrm{fed} / \mathrm{h}$ and $84.26 \%$, respectively. It was recommended to operate the developed harvester for harvesting onion crop at a depth harvesting of $10 \mathrm{~cm}$ and a forward speed of $0.720 \mathrm{~km} / \mathrm{h}$. Nisha and Shridar (2018) evaluated the performance of power tiller operated small onion harvester was field tested for harvesting $\mathrm{CO}$ (On) 5 varieties and they found that the field capacity was $0.08 \mathrm{ha} \mathrm{h}^{-1}$. The saving in cost and time were 59.2 and $93.75 \%$ respectively as compared to the conventional method of manual harvesting. The harvesting, conveying and soil separation efficiency of the developed harvester is $97.4,86.9$ and $84 \%$.

\section{Materials and Methods}

\section{Physical properties of onion}

The parameters influencing the digging of onion were identified and determined. We have measured the maximum depth of onion in the soil, onion stem height and width of onion coverage in the soil for Allium cepa 
variety. From these physical properties it is desired to design a digger blade which should not damage the onions during digging and should be able to dig and lift the onion from the soil.

\section{Comparison with traditional method}

In India most of the onion is harvested manually. Manual harvesting of onion is done by use of Khurpa or spade which is a labor intensive and time-consuming operation. This traditional method of digging is compared with self-propelled onion digger in terms of cost of digging and field capacity.

\section{Development of prototype onion digger}

A prototype onion digger was developed with Power unit, Power transmission unit, Blade, Ground wheel, handle and depth control wheel. The overall dimension of the selfpropelled onion digger is $1000 \mathrm{~mm} \times 870 \mathrm{~mm}$ $\times 1100 \mathrm{~mm}$. The main frame of the digger is fabricated to supports the components of onion digger such as speed reduction unit, pulley, power unit, wheels. Power required to run the onion digger was 4 hp with 3600 rated rpm and it is fixed on motor bed at a height of 40mm (Fig. 1).

\section{Pulley}

A compound belt drive, is used when power is transmitted from one shaft to another through number of pulleys. Speed reduction Pulleys are made up of cast iron and are connected by means of $\mathrm{V}$ belts.

$\pi D_{1} N_{1}=\pi D_{2} N_{2}$

Where

$N_{1}=$ Speed of driven pulley

$N_{2}=$ Speed of driver pulley

$D_{1}=$ Driven pulley diameter

$D_{2}=$ Driver pulley diameter
Reduction of $2800 \mathrm{rpm}$ to $25 \mathrm{rpm}$ is needed,

Pulley, $\mathrm{P} 1=3$ inch $(7.5 \mathrm{~cm})$

Pulley, P2 $=18$ inch $(45 \mathrm{~cm})$

Pulley, P3 = 3 inch $(7.5 \mathrm{~cm})$

Pulley, $\mathrm{P}_{4}=12$ inch $(28 \mathrm{~cm})$

Operation of walking speed $=2.3 \mathrm{~km} \cdot \mathrm{h}^{-1}$

Diameter of wheel $=50 \mathrm{~m}$

1 st Reduction $\mathrm{D}_{1} \mathrm{~N}_{1}=\pi \mathrm{D}_{2} \mathrm{~N}_{2}$

$\mathrm{N}_{2}=\frac{\mathrm{D} 1 \mathrm{~N} 1}{\mathrm{D} 2}=\frac{7.5 \times 2800}{45}=466.6 \mathrm{rpm}$

2 st Reduction

$\mathrm{N}_{4}=\frac{\mathrm{D} 3 \mathrm{~N} 3}{\mathrm{D} 4} \quad=^{\frac{7.5 \times 466.6}{4528}}=124 \mathrm{rpm}$

\section{Chain and sprocket}

Chain drive is a way of transmitting mechanical power from one place to another. A power transmission system takes place within a chain and two sprockets. The chain meshes with the sprockets, transmitting rotary motion between two sprockets (Fig. 2).

$3^{\text {rd }}$ reduction

$\mathrm{T}_{1} \mathrm{~N}_{5}=\mathrm{T}_{2} \mathrm{~N}_{6}$

$\mathrm{N} 6=\frac{\mathrm{T} 1 \mathrm{~N} 5}{\mathrm{~T} 2}=\frac{13 \times 124}{65}=25 \mathrm{rpm}$

With the help of pulley and chain sprocket $2800 \mathrm{rpm}$ is reduced to $25 \mathrm{rpm}$.

\section{Length of chain}

$\mathbf{L}=\frac{\pi}{2}\left(\mathbf{d}_{1}+\mathbf{d}_{2}\right)+2 \mathbf{x}+\frac{\left(d_{1}-d_{2}\right)^{2}}{4 x}$

Where,

$\mathrm{L}$ is length of chain

$\mathrm{d}$ is diameter of sprocket

$\mathrm{x}$ is center to center distance between shaft

Number of Teeth, $T_{1}=13, T_{2}=65$ 
Diameter of sprocket $d_{1}=5 \mathrm{~cm}, d_{2}=25 \mathrm{~cm}$

Center to center distance, $\mathrm{x}=20 \mathrm{~cm}$

$\mathrm{L}=\frac{\frac{3.14}{2}}{2}(5+25)+2 \times 20+\frac{(5-25)^{2}}{4 \times 25}$
$\mathrm{~L}=92.1 \mathrm{~cm}$

V Belt: V- Type of belt used for connecting the pulleys, where a same amount of power is to be transmitted, from one pulley to another pulley. The pulley is mounted on the shaft that are parallel to each other (Fig.1).

\section{Length of belt for $1^{\text {st }}$ reduction}

Diameterofpulleyd $\mathrm{d}_{1}=7.5 \mathrm{~cm}, \mathrm{~d}_{2}=45 \mathrm{~cm}$ and Centre to centre distance $\mathrm{x}=35 \mathrm{~cm}$

$\mathrm{L}=\frac{\pi}{2}\left(d_{1}+d_{2}\right)+2 \mathrm{x}+\frac{\left(d_{1}-d_{2}\right)^{2}}{4 x}$

$\mathrm{L}=(1.57 \times 52.5)+40+10.038$

$\mathrm{L}=162.46 \mathrm{~cm}$ (or) 65 inchso $65 \mathrm{~B}$ type pulley was chosen.

\section{Length of belt for $2^{\text {nd }}$ reduction}

Diameter of pulleyd $d_{1}=7.5 \mathrm{~cm}, \mathrm{~d}_{2}=45 \mathrm{~cm}$ and Centre to centre distance $x=32 \mathrm{~cm}$ therefore $\mathrm{L}=123 \mathrm{~cm}$, so $\mathrm{V}$ belt of $49 \mathrm{~B}$ type pulley was chosen.

\section{Power transmission unit}

A $4 \mathrm{hp}$ air cooled petrol engine is fitted on the main frame at an appropriate place. Provision is made at the base point to move the engine to create a belt tension with the help of $\mathrm{V}$ pulley fitted to the engine and compound $\mathrm{V}$ belts. It also provided the tension mechanism to create belt tension or slack at necessary time.

\section{Digging blade}

Mild steel Blade is used to dig the onions and height, width and thickness of the blade is 170,75 and $6 \mathrm{~mm}$ respectively. The cutting edge of the blade is provided with an angle of $45^{\circ}$ for $50 \mathrm{~mm}$ height (Fig. 3).

\section{Handle}

The handle is provided at the rear side of the digger to hold and steers the machine. The handles are made of $250 \mathrm{~mm}$ mild steel hallow circular pipe. The length of the handle is 900 $\mathrm{mm}$ and $550 \mathrm{~mm}$ twisted is given at the purpose of connection. The length of the handle crossbar is $175 \mathrm{~mm}$ which is provided between two handles for providing stability (Fig. 2).

\section{Ground wheel and shaft}

A light weight ground wheel is attached to the digger for the traction of implement. The ground wheel is $600 \mathrm{~mm}$ in diameter with 100 mm width and it is made of $12 \mathrm{~mm}$ mild steel round rod, the clearance between the ground wheel were adjustable according to the ridge spacing. The ground wheel has a shaft with a diameter of $25 \mathrm{~mm}$ with a length of $900 \mathrm{~mm}$ which connects the main frame and the two wheels (Fig. 4).

\section{Depth control wheel}

The depth control wheel with a diameter of $200 \mathrm{~mm}$ and the width of $20 \mathrm{~mm}$ is fixed at the rear side of digging tool bar. The depth can be varied according to the digging depth. The square tube is attached to the depth wheel which consists of number of holes which is used to change the height of the depth wheel (Fig. 2).

\section{Performance evaluation of self-propelled onion digger}

The harvesting efficiency of the onion digger was studied using a portable onion digger. The parameters recorded while evaluating the performance of the digger were operational speed of digger, depth of operation, Weight of 
onion lifted, weight of onion damaged and Weight of onion left undigged. Onions were transplanted on $60 \mathrm{~cm}$ wide bed with row to row spacing of $15 \mathrm{~cm}$ and plant to plant spacing of $7.5 \mathrm{~cm}$ (Fig. 5). The onion was harvested at the age of 107 days after sowing.

\section{Field capacity}

The field capacity and field efficiency of the unit was found by operating the unit in an area of 50 cent. The total time taken to cover the area, time lost for running at head lands and other time losses were recorded for the calculation of field capacity.

Theoretical field capacity $=\mathrm{W} * \mathrm{~S}$

Where W - Width of operation

$\mathrm{S}$ - Speed of operation

Actual field capacity is the actual area covered by the self-propelled onion digger in a particular time.

\section{Digging efficiency}

The digger efficiency was calculated using the equation given below (Ibrahim et al., 2008).

$\eta=(\mathrm{Wr} /(\mathrm{Wr}+\mathrm{Ws})) \times 100$

Where,

$\eta$ - harvesting efficiency, per cent

$\mathrm{Wr}$ - weight of onion collected from harvesting the clumps in unit area, $\mathrm{kg}$

Ws - weight of undug onion bulbs collected from the soil in unit area, $\mathrm{kg}$

\section{Field efficiency}

The field efficiency is the ratio of effective field capacity to theoretical field capacity of the machine.

\section{Percentage of damaged bulbs}

The damage percentage was calculated using the equation given below (Ibrahim et al., 2008).

$$
\mathbf{D}=\left(\mathbf{N}_{\mathrm{d}} / \mathbf{N}_{\mathrm{t}}\right) \times \mathbf{1 0 0}
$$

Where, $\quad \mathrm{N}_{\mathrm{d}}$ is the total number of damaged bulbs,

$\mathrm{N}_{\mathrm{t}}$ is the total number of bulbs

From the data collected from each plot, the coverage, cost of harvesting and harvesting efficiency was calculated.

\section{Cost economics}

The total cost of the onion digger was arrived and fixed and variable costs for operating the onion digger unit per hour are also calculated. This cost was compared with manual method. Payback period and savings in cost and time using the onion digger was also arrived.

\section{Results and Discussion}

\section{Physical properties}

The physical properties determined experimentally were the depth of onion, area of onion coverage and shoot height of onion.

From Table 1 it is inferred that the average depth of onion bulb varied from 10 to $16 \mathrm{~cm}$. The average shoot height for Allium cepa variety varied from 14 to $22 \mathrm{~cm}$ and the average area of onion bulb coverage varied from 5 to $8 \mathrm{~cm}$.

\section{Self-propelled onion digger compared with conventional methods}

Manual harvesting of onion is done by use of khurpa or spade which is a labor intensive and 
time-consuming operation. It is suitable for only small land holders for their own use. The field capacity of manual digging of onion by khurpa is $0.015 \mathrm{ha} / \mathrm{h}$. and it was less than the portable Self-propelled onion digger with field capacity of $0.12 \mathrm{ha} / \mathrm{h}$.
Digging efficiency of self-propelled onion digger

The onion digger was fabricated and was tested by varying the level of factors such as forward speed and depth of operation. The results obtained are discussed in the following sections (Table 2).

Table.1 Depth of onion, shoot height and area of onion coverage

\begin{tabular}{|c|c|c|c|}
\hline Name of the plot & Height of $\operatorname{shoot}(\mathrm{cm})$ & $\begin{array}{l}\text { Area of onion } \\
\text { coverage, }\left(\mathrm{cm}^{2}\right)\end{array}$ & Depth of onion (cm) \\
\hline Plot 1 & 15 & 7.5 & 12 \\
\hline Plot2 & 18.2 & 6 & 13 \\
\hline Plot 3 & 14 & 8.1 & 11 \\
\hline Plot 4 & 17 & 8 & 10 \\
\hline Plot 5 & 19 & 6 & 15 \\
\hline Plot 6 & 20 & 5 & 14 \\
\hline Plot 7 & 22 & 8 & 12 \\
\hline Plot 8 & 19 & 7 & 12 \\
\hline Plot 9 & 16 & 6.9 & 16 \\
\hline Plot 10 & 18 & 8 & 13 \\
\hline
\end{tabular}

Table.2 Speed of operation and digging efficiency

\begin{tabular}{|c|c|c|c|c|}
\hline $\begin{array}{c}\text { Speed of } \\
\text { Operation(km/h) }\end{array}$ & \multicolumn{3}{|l|}{ Digging efficiency (\%) } & Average \\
\cline { 2 - 5 } & Plot1 & Plot2 & Plot3 & \\
\hline $\mathbf{2}$ & 97 & 97.5 & 97 & $\mathbf{9 7}$ \\
\hline $\mathbf{2 . 3}$ & 95 & 95.5 & 96 & $\mathbf{9 5 . 5}$ \\
\hline $\mathbf{2 . 5}$ & $\mathbf{9 4}$ & $\mathbf{9 4}$ & $\mathbf{9 4}$ & $\mathbf{9 4}$ \\
\hline
\end{tabular}


Table.3 Depth of operation and digging efficiency

\begin{tabular}{|c|c|c|c|c|}
\hline \multirow{2}{*}{$\begin{array}{c}\text { Depth of } \\
\text { Operation }(\mathbf{c m})\end{array}$} & \multicolumn{3}{|c|}{ Digging efficiency (\%) } & \multirow[t]{2}{*}{ Average } \\
\hline & Plot 1 & Plot2 & Plot3 & \\
\hline 12 & 90 & 88 & 89 & 88 \\
\hline 15 & 92 & 93 & 94 & 93 \\
\hline 20 & 98 & 97 & 99 & 98 \\
\hline
\end{tabular}

Table.4 Forward speed on percentage of bulb damage

\begin{tabular}{|c|c|c|c|c|}
\hline $\begin{array}{c}\text { Speed of } \\
\text { operation(km/h) }\end{array}$ & \multicolumn{3}{|c|}{ Bulb damage \% } & Average \\
\cline { 2 - 5 } & Plot1 & Plot2 & Plot3 & \\
\hline 2 & 1 & 2 & 1 & 1.33 \\
\hline 2.3 & 2 & 3 & 3 & 2.67 \\
\hline 2.5 & 4 & 4 & 3 & 3.67 \\
\hline
\end{tabular}

Table.5 Depth of operation on percentage of bulb damage

\begin{tabular}{|c|c|c|c|c|}
\hline \multirow{2}{*}{$\begin{array}{c}\text { depth of } \\
\text { operation(cm) }\end{array}$} & \multicolumn{3}{|c|}{ Bulb damage \% } & Average \\
\cline { 2 - 5 } & Plot1 & Plot2 & Plot3 & \\
\hline 12 & 9 & 11 & 13 & 11 \\
\hline 15 & 4 & 5 & 4 & 4.34 \\
\hline 20 & 1 & 2 & 2 & $\mathbf{1 . 6 7}$ \\
\hline
\end{tabular}

Table.6 Cost economics

\begin{tabular}{|l|l|l|}
\hline Particulars & \multicolumn{1}{|c|}{$\begin{array}{c}\text { Self-propelled onion } \\
\text { digger }\end{array}$} & $\begin{array}{l}\text { Manual method } \\
\text { (Khurpa) }\end{array}$ \\
\hline Cost of operation per hectare, Rs. & 867 & 4800 \\
\hline Cost of operation per hour & 102 & 50 \\
\hline Area covered, ha.h ${ }^{-1}$ & 0.12 & 0.01 \\
\hline Time required to cover one hectare & 8 and half & $96-$ man hour \\
\hline Saving in cost, percent & 81.9 & - \\
\hline Saving in time, percent & 91.3 & - \\
\hline
\end{tabular}

Fig.1 Onion digger-front view 


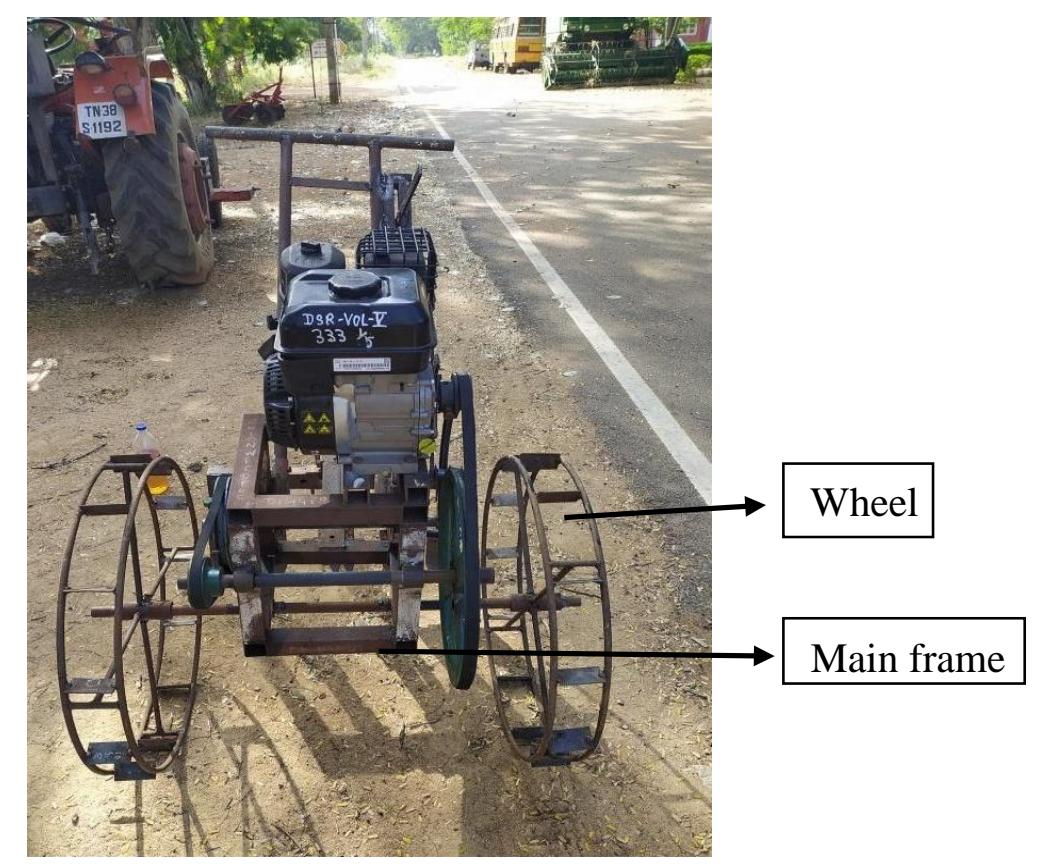

Fig.2 Onion digger-Isometric view

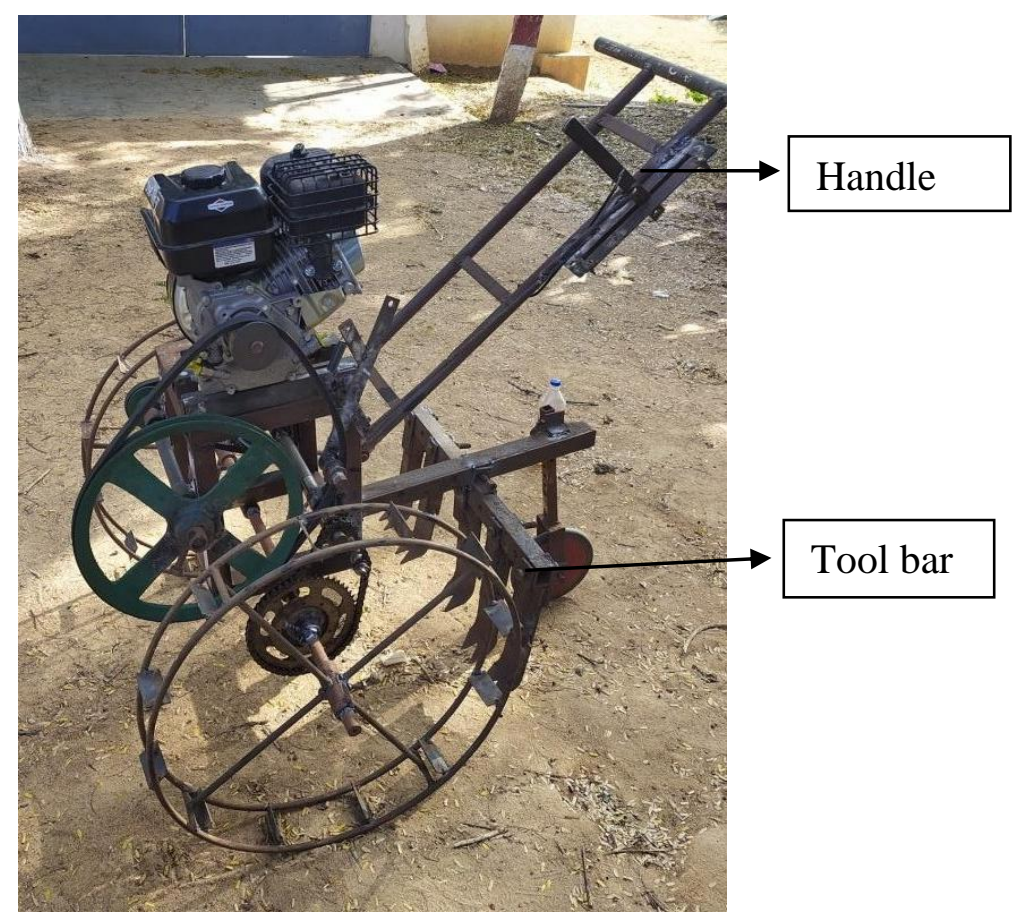




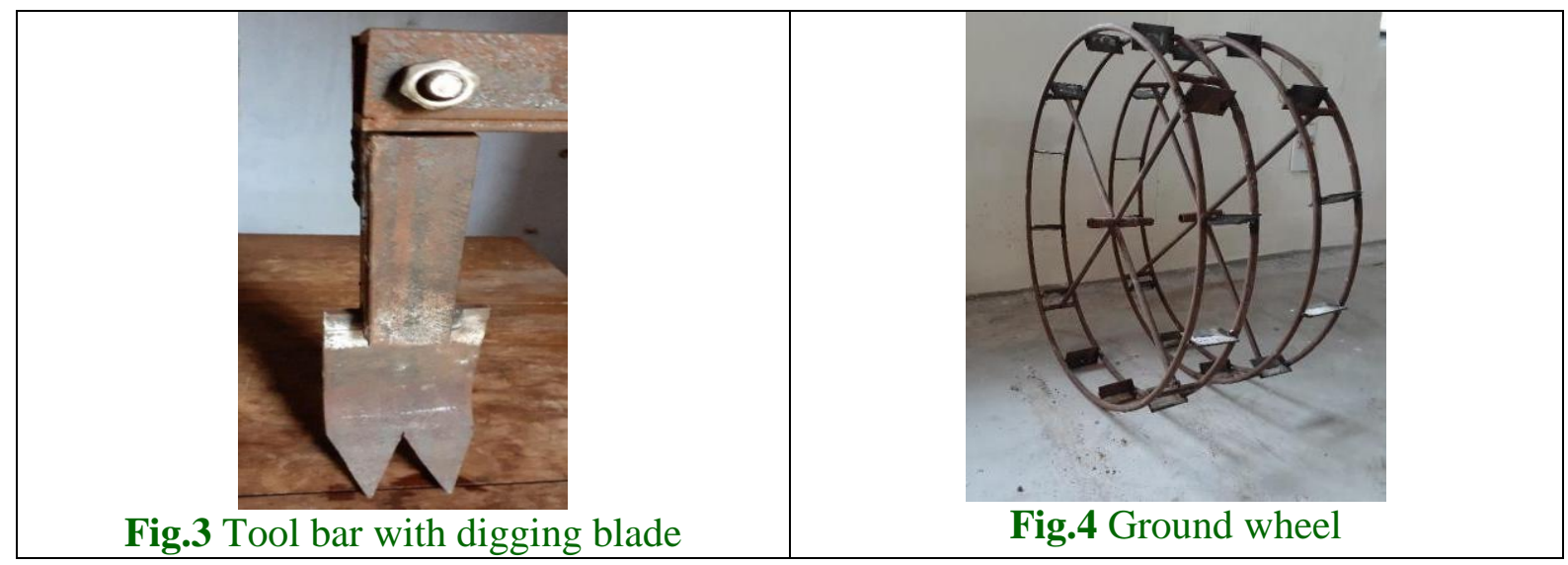

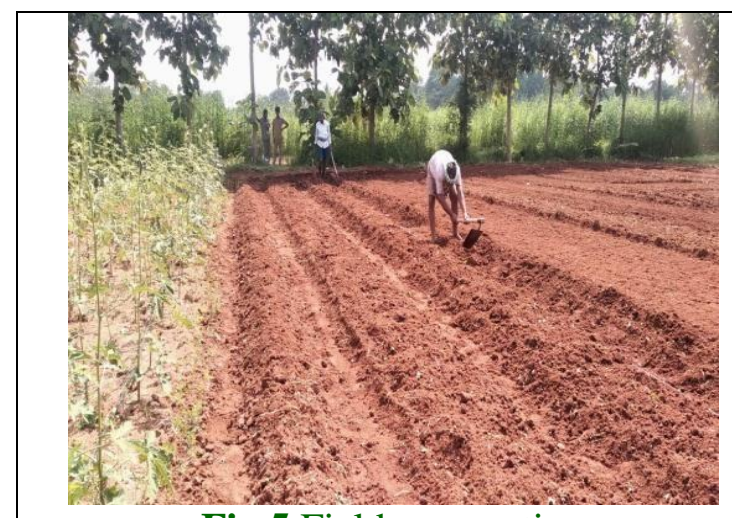

Fig.5 Field preparation

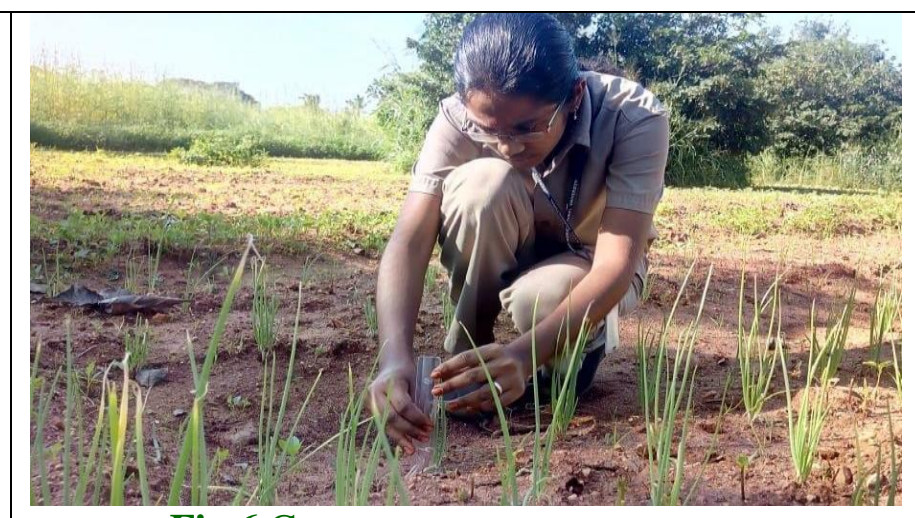

Fig.6 Crop parameter measurement
Effect of forward speed on digging efficiency

The effect of forward speed on digging efficiency was shown in Fig. 2. It is seen that the increase in speed of operation from 2 to $2.5 \mathrm{~km} / \mathrm{h}$ digging efficiency was decreased. The maximum average digging efficiency of $97 \%$ could be achieved at a forward speed 2 $\mathrm{km} \mathrm{h}^{-1}$.

\section{Effect of depth of operation on digging efficiency}

From table 3 it is seen that there was a trend of increase in digging efficiency with gradual increase in the depth of operation. The digging efficiency at $12 \mathrm{~cm}$ depth is $88 \%$ and it increases to $93 \%$ at $15 \mathrm{~cm}$ depth and it is further increased to $98 \%$ at $20 \mathrm{~cm}$ depth of operation.
Percentage of bulb damage of selfpropelled onion digger

Effect of forward speed on percentage of onion bulb damage

The effect of speed of operation on percentage of plant damage was shown in table 4 , it is seen that there was a trend of increase in percentage of plant damage with gradual increase in the speed of operation. The percentage of plant damage at $2 \mathrm{~km} / \mathrm{h}$ is $1.33 \%$ and it is increased to $2.67 \%$ at $2.3 \mathrm{~km} / \mathrm{h}$ and it is further increased to 3.67 at $2.5 \mathrm{~km} / \mathrm{h}$.

\section{Effect of depth of operation on percentage of bulb damage}

From table 5 it is seen that there was a trend of decrease in percentage of plant damage with gradual increase in the depth of 
operation. The percentage of plant damage at $12 \mathrm{~cm}$ depth of operation is $11 \%$ and at $15 \mathrm{~cm}$ depth of operation is $4.34 \%$ and at $20 \mathrm{~cm}$ depth of operation percentage of plant damage reduces to $1.67 \%$ (Fig. 6).

\section{Cost economics}

The cost economics of the developed onion digger was worked out and compared with manual digging method (Table 6).

In conclusion, the performance of Selfpropelled onion digger was studied and compared with Manual method. The average shoot height was $17.82 \mathrm{~cm}$ and the average area of coverage of onion bulb in soil was $7.05 \mathrm{~cm}^{2}$. The maximum digging efficiency $97 \%$ was achieved at forward speed of $2 \mathrm{~km} / \mathrm{h}$ with $20 \mathrm{~cm}$ depth of operation. The minimum percentage of bulb damage of $1.67 \%$ was achieved at forward speed of $2 \mathrm{~km} / \mathrm{h}$ and at depth of $20 \mathrm{~cm}$. The field capacity of the self-propelled onion digger was found to be $0.12 \mathrm{ha} / \mathrm{h}$. The saving in cost and time were $81.9 \%$ and $91.3 \%$ respectively as compared to convention method of onion harvesting.

\section{References}

Anonymous (2017). Horticultural Statistics at a Glance, Pp. 16, 454 and 470.

Budhale, K. C., A. G. Patil, V. S. Shirole, S. S. Patil, R. S. Desai and Salavi, S. B. 2019. Design and development of digging \& conveyor system for self- propelled onion harvester. International Research Journal of Engineering and Technology. 6(4): 3304-3307.

Omar, O.A., G. Soha, Abdel Hamid and ElTermzy, G.A. 2018. Development of an onion-crop harvester. Misr J. Ag. Eng., 35(1): 39-56.

Nisha, N and Shridar, B. 2018. Development of power tiller operated harvester, for small onion (Allium cepa var. Aggregatum). International Journal of Agricultural Science and Research. 8(1): 73-78.

Ashwini Talokar, V., P. Khambalkar and Kanchan Wankhade. 2014. Design of onion harvester. International Journal \& Magazine of Engineering, Technology, Management and Research. 1(3): 11-16.

JafarMassah, Ahmad Lotfi and Akbar Arabhosseini. 2012. Effect of blade angle and speed of onion harvester on mechanical damage of onion bulbs. Agricultural Mechanization in Asia, Africa, and Latin America. 43 (3): 6064

Lorenzo, M., Abenavoli, and Stefano Morabito F G., 2004. Onion: harvesting and post- harvesting mechanized operations. CIGR International Conference, Beijing. Sponsored by CIGR, CSAM and CSAE Beijing, China 11- 14 October 2004, 1-11.

Mahesh, C.S., 2014. Development and performance evaluation of a digger for harvesting onion (Allium cepa L.). International Journal of Agric. Eng. 7(10): 391- 394.

\section{How to cite this article:}

Dhananchezhiyan, P., P.K. Nanthinee, E. Naveen Kumar and Parthiban, P. 2020. Development of Self-Propelled Onion Digger for Small Farmers. Int.J.Curr.Microbiol.App.Sci. 9(11): 31033112. doi: https://doi.org/10.20546/ijcmas.2020.911.374 